\title{
The effectiveness of Bunaken National Park management
}

\author{
Efektivitas Pengelolaan Taman Nasional Bunaken \\ Abraham W. Manumpil ${ }^{1 *}$, Stephanus V. Mandagi², and Markus T. Lasut ${ }^{2}$ \\ ${ }^{1}$ Program Studi Ilmu Perairan, Program Pascasarjana Universitas Sam Ratulangi. Jln. Kampus Unsrat Kleak, \\ Manado 95115, Sulawesi Utara, Indonesia. \\ ${ }^{2}$ Fakultas Perikanan dan Ilmu Kelautan, Universitas Sam Ratulangi. Jl. Kampus Unsrat Bahu, Manado 95115, \\ Sulawesi Utara, Indonesia. \\ *E-mail: abraham.manumpil@gmail.com
}

\begin{abstract}
The important values of Bunaken National Park were gathered through interviews with 80 respondents in order to obtain local people's opinion of the marine park. Results showed that the most important value was coral reefs, holding $68.75 \%$ of the respondents' opinion. Moreover, they put the environmental characteristics, such as fish, biodiversity, and mangrove, as major values of Bunaken National Park. Many respondents mentioned the economic values in relation with tourism business. As many as $11.25 \%$ of the respondents claimed that the presence of management and its programs was main value of the marine park. The respondents' opinion concerning the threat on the major values of Bunaken National Park found that nearly all respondents mentioned several deleterious behaviors that could directly demolish natural environmental values, such as fish blasting, fish poisoning, pollution and illegal mangrove cutting. Illegal entry of the zonation and excessive exploitation from commercial fishing operations or fish netting, and low awareness were also found. In addition, $8.75 \%$ of the respondents claimed that economic or poverty issues were major threats on Bunaken National Park values, and 5\% thought that government policy was the serious threat. This study revealed that Bunaken National Park has been effectively managed. It is indicated by a good patrol system and better social economic condition of the communities living inside the park.
\end{abstract}

Keywords: marine protected area; coastal zone management; Bunaken National Park; Indonesia.

Abstrak: Hasil penelitian menunjukkan tentang pandangan masyarakat lokal terhadap nilai-nilai penting Taman Nasional Bunaken, yang dilakukan melalui wawancara terhadap 80 responden untuk mendapatkan daftar apa saja yang menurut mereka nilai-nilai paling penting dari Taman Nasional Bunaken. Nilai terpenting menurut responden adalah terumbu karang $(68,75 \%)$. Selanjutnya, responden menempatkan karakteristik lingkungan, seperti ikan, keragaman biologis, dan mangrove, merupakan nilai utama dari Taman Nasional Bunaken. Banyak responden juga menyebutkan nilai-nilai ekonomis yang dihubungkan dengan bisnis pariwisata. Sebanyak $11.25 \%$ responden berkomentar, bahwa adanya pengelolaan dan program-programnya merupakan nilai-nilai utama dari Taman Nasional Bunaken. Hasil wawancara tentang pandangan responden mengenai ancamanancaman terhadap nilai-nilai utama Taman Nasional Bunaken menunjukkan, bahwa hampir semua responden menyebutkan beberapa tingkah laku yang merusak yang secara langsung menghancurkan nilai-nilai lingkungan alami, misalnya bom ikan, racun ikan, polusi, dan penebangan mangrove secara ilegal. Pelanggaran zonasi dan eksploitasi berlebihan melalui operasi-operasi komersil atau penangkapan ikan dengan jaring, kurangnya kesadaran juga disebutkan. Sebanyak $8.75 \%$ responden mengatakan, bahwa isu ekonomi atau kemiskinan merupakan ancaman utama terhadap nilai-nilai Taman Nasional Bunaken; dan 5\% responden yang mengatakan, bahwa kebijakan pemerintah merupakan ancaman serius. Penelitian ini mendapati, bahwa Taman Nasional Bunaken telah dikelola secara efektif. Hal ini diindikasikan dengan adanya suatu sistem patroli yang berjalan dengan baik dan peningkatan kondisi sosial ekonomi masyarakat di kawasan Taman Nasional Bunaken.

Kata-kata kunci: daerah perlindungan laut; pengelolaan wilayah pesisir; taman nasional Bunaken; Indonesia.

\section{PENDAHULUAN}

Informasi yang dapat menggambarkan tentang efektivitas pengelolaan Taman Nasional Bunaken sangat penting dalam rangka menentukan strategi pengembangan yang paling tepat. Penilaian efektivitas suatu kawasan konservasi tidak hanya mencari masalah dan solusinya tetapi mengidentifikasi apakah pengelolaan kawasan tersebut berjalan dengan baik; di samping itu juga, dapat meningkatkan akuntabilitas dan pelaporan serta dapat membantu perencanaan selanjutnya. Berdasarkan uraian tersebut di atas, adapun tujuan dalam penelitian ini adalah sebagai berikut: 
mengevaluasi efektivitas pelaksanaan pengelolaan Taman Nasional Bunaken, dan membuat rekomendasi untuk meningkatkan efektivitas pengelolaan Taman Nasional Bunaken.

\section{MATERIAL DAN METODA}

Penelitian dilaksanakan selama 5 bulan, sejak April - September 2015 di Kawasan Taman Nasional Bunaken, Provinsi Sulawesi Utara. Penelitian ini pada dasarnya model survei dan bersifat eksploratoris-deskriptif sehingga tidak ada hipotesis yang muncul.

Data primer dan sekunder telah dikumpulkan selama penelitian. Data primer terdiri dari, data hasil diskusi kelompok dengan menggunakan metode Focus Group Disscusion (FGD) dan interview. Sedangkan data sekunder, yaitu kelembagaan dan rencana pengelolaan dari Taman Nasional Bunaken. Pengambilan titik sampel di daerah penelitian dilakukan di Taman Nasional Bunaken bagian Selatan (Desa Poopoh, Kumu, Arakan), bagian Utara (Bunaken, Mantehage, Molas, Meras dan Tongkaina).

Kerangka kerja untuk menilai keefektifan pengelolaan yang dikembangkan oleh IUCN's World Commission for Protected Area (WCPA) didasarkan atas pemikiran, bahwa pengelolaan mengikuti suatu proses. Proses ini mempunyai enam langkah atau elemen, yaitu: konteks, perencanaan, masukan, proses, keluaran, dan hasil. Keenam komponen ini bersifat saling melengkapi satu dengan lainnya. Konteks dan perencanaan berhubungan dengan desain kawasan konservasi.
Masukan dan proses berhubungan dengan berbagai sistem pengelolaan/struktur dan proses. Keluaran dan dampak berhubungan dengan penyaluran berbagai hasil atau sasaran yang dicapai.

\section{HASIL DAN PEMBAHASAN}

Berdasarkan data yang diperoleh, maka berikut ini disajikan keenam elemen utama yang menjadi fokus penelitian ini.

1. Konteks (bagaimana status nilai, ancaman, dan isu di pengelolaan Taman Nasional Bunaken)

a. Arti penting nilai-nilai TNB

Pandangan lokal terhadap nilai-nilai penting di Taman Nasional Bunaken dilakukan dengan wawancara terhadap 80 responden untuk mendapatkan daftar apa saja yang menurut mereka nilai-nilai paling penting di Taman Nasional Bunaken di mana masing-masing responden menjawab lebih dari satu jawaban sehingga persentasi yang ada dalam grafik merupakan total jawaban yang diberikan (Gambar 1). Nilai terpenting, menurut responden, adalah terumbu karang (68,75\%). Selanjutnya, responden menempatkan karakteristik lingkungan, seperti ikan, keragaman biologis, dan mangrove, merupakan nilai utama dari Taman Nasional Bunaken. Banyak responden juga menyebutkan nilai-nilai ekonomis yang dihubungkan dengan bisnis pariwisata. Sebanyak 11,25\% responden berkomentar, bahwa adanya pengelolaan dan program-programnya merupakan nilai-nilai utama di TNB.

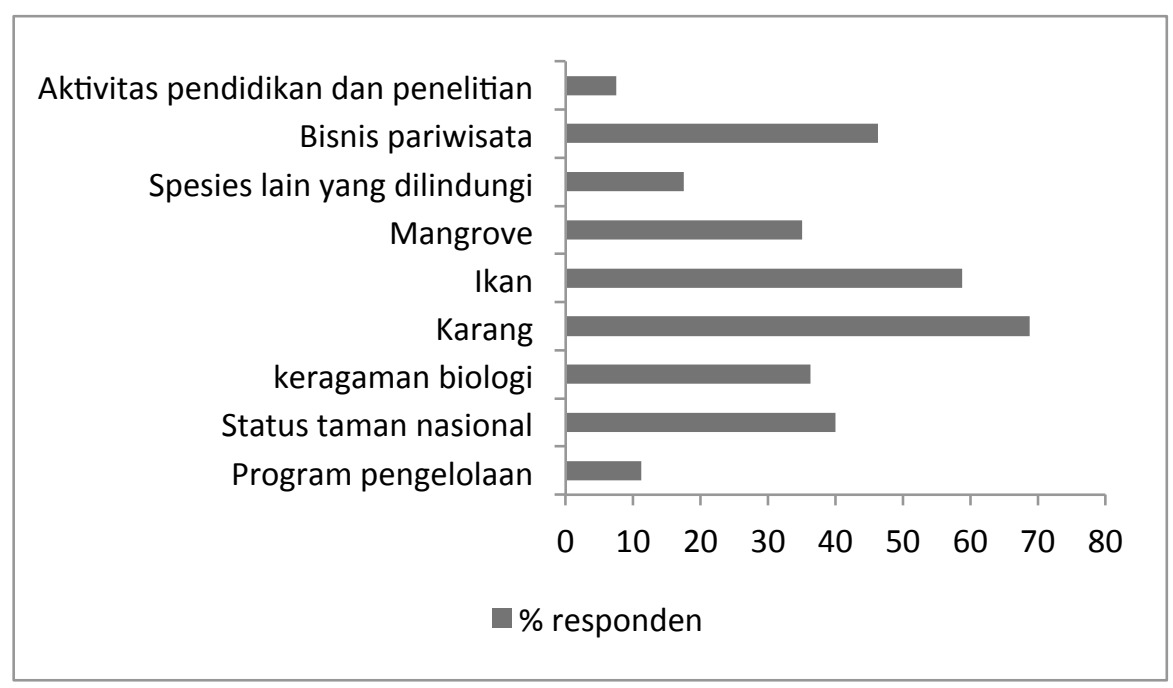

Gambar 1. Pandangan Responden tentang nilai-nilai paling penting dari Taman Nasional Bunaken. 


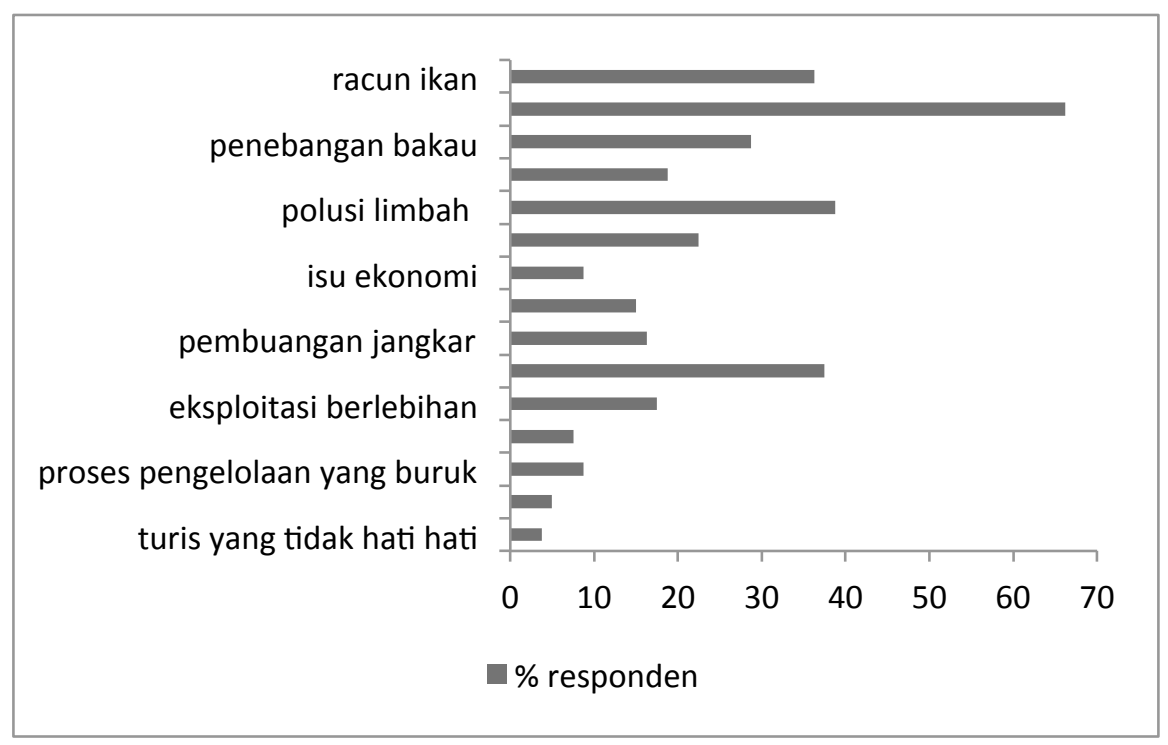

Gambar 2. Pandangan respoden mengenai ancaman yang paling serius terhadap nilai- nilai TNB.

b. Ancaman terhadap nilai-nilai Taman Nasional Bunaken

Hasil wawancara tentang pandangan responden mengenai ancaman-ancaman terhadap nilai-nilai utama di Taman Nasional Bunaken (Gambar 2) menunjukkan, bahwa lebih dari 75\% responden menyebutkan beberapa tingkah laku yang merusak yang secara langsung menghancurkan nilai-nilai lingkungan alami, misalnya bom ikan, polusi limbah, racun ikan, dan penebangan mangrove ilegal. Pelanggaran zonasi dan eksploitasi berlebihan melalui operasi-operasi komersil atau penangkapan ikan dengan jaring, kurangnya kesadaran juga sering disebutkan. Sebanyak $8,75 \%$ responden mengatakan, bahwa isu ekonomi atau kemiskinan merupakan ancaman utama terhadap nilai-nilai di Taman Nasional Bunaken dan $5 \%$ responden yang mengatakan bahwa kebijakan pemerintah adalah ancaman serius.

2. Perencanaan (seberapa cukup perencanaan dan kebijakan untuk mengelola Taman Nasional Bunaken)

Hasil diskusi dengan pengelola Taman Nasional Bunaken diperoleh, setidaknya terdapat 4 kegiatan utama yang sampai saat ini masih terus dilakukan dan dikembangkan oleh pengelola Taman Nasional Bunaken, yaitu: 1) penerapan dan penegakan aturan zonasi di mana kawasan dibagi berdasarkan peruntukan yang tepat, 2) komunikasi, informasi, dan pendidikan masyarakat di dalam dan sekitar kawasan taman nasional, 3) penelitian ilmiah, untuk mengembangkan, mengevaluasi, dan menyempurnakan kebijakan pemanfaatan sumber daya alam Taman Nasional Bunaken, serta untuk mengevaluasi dampak kegiatan pembangunan di luar (sekitar) kawasan, dan 4) pengembangan koordinasi kegiatan semua pihak terkait (instansi pemerintah, kepolisian, lembaga penelitian dan pendidikan, masyarakat setempat, lembaga swadaya masyarakat, dan sektor swasta) untuk meningkatkan kegiatan pengelolaan taman nasional.

3. Masukan (seberapa cukup sumberdaya yang tersedia saat ini untuk mengelola Taman Nasional Bunaken)

Pengelolaan kawasan konservasi memerlukan waktu dan upaya. Dibutuhkan sumber daya yang cukup bagi personil untuk berfungsi dengan efisien dan efektif dalam mencapai tujuan pengelolaan kawasan konservasi, juga dibutuhkan infrastruktur penunjang. Selain dari lembaga pengelola Taman Nasional Bunaken, didukung juga oleh kemitraan yang berpartisipasi dalam sistem pengelolaan Taman Nasional Bunaken (perwakilan pemerintah dan non-pemerintah).

\section{Proses}

Sebelum tahun 2000, satu-satunya lembaga yang bertanggung jawab terhadap pengelolaan Taman Nasional Bunaken adalah Balai Taman Nasional Bunaken. Situasi pengelolaan pada saat itu menghadapi banyak persoalan konflik akibat kurangnya perwakilan dan konsistensi dalam proses dan program pengelolaan. Hampir setiap perubahan struktur dan proses pengambilan keputusan sejak saat itu dapat dianggap sebagai perbaikan yang didorong oleh tuntutan aspirasi para pihak terlibat. 
Sejak Forum Masyarakat Peduli Taman Nasional Bunaken, sistem tarif masuk, dan Dewan Pengelola Taman Nasional Bunaken terbentuk dan mulai bekerja pada awal tahun 2000, tanggung jawab pengelolaan terbagi di antara tiga lembaga yang berbeda, yang masing-masing memiliki peran saling melengkapi (managemen kolabolatif). Balai Taman Nasional Bunaken tetap sebagai lembaga pemegang otoritas utama dalam pengambilan keputusan pengelolaan dan kegiatan dalam kawasan. Dewan Pengelolaan Taman Nasional Bunaken dan Forum Masyarakat Peduli Taman Nasional Bunaken, masing-masing mendukung Balai Taman Nasional Bunaken dengan cara yang berbeda. Dewan Pengelolaan Taman Nasional Bunaken yang bersifat multi-pihak memungkinkan adanya sistem perwakilan dalam proses-proses (misalnya: pembuatan keputusan dalam pengelolaan dana tarif masuk; koordinasi kegiatan dari berbagai intansi pemerintah dan lembaga non pemerintah; dan memberikan saran, nasehat dan rekomendasi kepada Balai Taman Nasional Bunaken). Forum Masyarakat Peduli Taman Nasional Bunaken memberikan wadah dan mekanisme bagi perwakilan masyarakat setempat dan mempercepat komunikasi antara masyarakat dan lembagalembaga yang terlibat dalam pengelolaan kawasan.

Berdasarkan informasi yang diperoleh dari pengelola Taman Nasional Bunaken, sistem tarif, yang selama ini dikelola oleh Dewan Pengelola Taman Nasional Bunaken, dialihkan pengelolaannya ke Balai Taman Nasional Bunaken yang didukung oleh Peraturan Pemerintah Republik Indonesia nomor 12 Tahun 2014 yang berlaku pada Kementrian Kehutanan. Dengan keluarnya aturan tentang pengelolaan tarif masuk ini, maka sejak Februari tahun 2015 pihak Balai Taman Nasional Bunaken telah mengelola sistem tarif tersebut dan hal ini berdampak besar terhadap keberadaan organisasi Dewan Pengelola Taman Nasional Bunaken dan Forum Masyarakat Peduli Taman Nasional Bunaken yang bergantung pada tarif masuk tersebut.

5. Keluaran (produk-produk dan jasa-jasa apa yang telah diberikan pengelola dan implementasi rencana pengelolaan)

\section{a. Sistem pengawasan (Patroli)}

Wawancara yang dilakukan dengan berbagai pihak tentang sistem patroli, termasuk juga pandangan masyarakat, diperoleh informasi sebagai berikut: responden yang diwawancarai mengatakan, bahwa umumnya sistem patroli sekarang ini lebih baik dibandingkan situasi tiga tahun lalu (Gambar
3). Responden yang menjawab situasi sekarang ini sama dengan situasi tiga tahun lalu, kebanyakan menilai sistem patroli sekarang cukup baik.

\section{b. Zonasi}

Taman Nasional Bunaken telah memberlakukan sistem zonasi sejak tahun 1997, berdasarkan SK. DIRJEN PHPA No. 147/Kpts./DJ-VI/1997, dan zonasi ini telah direvisi dengan terbitnya SK. DIRJEN PHKA No. SK. 13/IV-KK/2008. Untuk mendukung pengelolaan, Balai TNB memiliki rencana pengelolaan 25 tahun, rencana lima tahunan, rencana kerja tahunan dan anggaran. Beberapa program kerja telah disusun dalam mengemban tugas dan fungsi pengelolaan ekosistem kawasan taman nasional, serta mendukung visi "terwujudnya Taman Nasional yang aman dan lestari didukung kelembagaan yang kuat dalam pengelolaannya serta mampu memberikan manfaat optimal kepada masyarakat. “

c. Kegiatan-kegiatan Peningkatan Kesadaran dan Pengembangan Masyarakat

Berdasarkan hasil wawancara dan observasi di lapangan ditemukan beberapa fakta yang berhubungan dengan kegiatan peningkatan kesadaran dan pengembangan masyarakat, yaitu:

\section{- Papan informasi}

Papan informasi telah dipasang di setiap desa yang masuk dalam kawasan Taman Nasional Bunaken. Pembuatan papan informasi ini didorong oleh adanya kelemahan di mana masyarakat kurang mendapatkan informasi yang benar mengenai konservasi dan pengelolaan Taman Nasional Bunaken yang dapat meningkatkan pemahaman dan meningkatkan "rasa memiliki" dalam masyarakat untuk ikut terlibat dalam pengelolaan.

\section{- Kaderisasi Konservasi oleh Balai Taman Nasional Bunaken}

Pendidikan kader konservasi dilaksanakan hampir setiap tahun oleh Balai Taman Nasional Bunaken; dengan target kaum muda, siswa sekolah dan perguruan tinggi dari dalam kawasan dan dari sekitar Kota Manado. Kegiatan ini merupakan salah satu upaya pendidikan konservasi dan peningkatan kesadaran kaum muda dan untuk menciptakan kelompok-kelompok sukarelawan yang diharapkan dapat membantu kegiatan-kegiatan konservasi di Taman Nasional Bunaken.

\section{- Proyek Kampanye Pride}

Kampanye Pride di Taman Nasional Bunaken difokuskan di Pulau Mantehage. Tujuan dari 
kampanye pride ini adalah mendorong para nelayan untuk menggunakan teknik penangkapan ikan yang ramah lingkungan, memberikan hasil tangkapan ikan yang banyak dengan memelihara sumber perikanan tersebut. Selain itu, nelayan juga didorong untuk mematuhi aturan zonasi Taman Nasional Bunaken (SK. Dirjen PHKA No. 13/IVKK/2008), khususnya zona larang tangkap yang telah ada.

\section{d. Sistem Tarif Masuk}

Sistem tarif masuk Taman Nasional Bunaken diatur dalam Peraturan Daerah Provinsi Sulawesi Utara Nomor 14 tahun 2000 tentang Pungutan Masuk Taman Nasional Bunaken yang disempurnakan dengan Perda Nomor 49 tahun 2001. Besarnya tarif, sebagai berikut: pengunjung asing sebesar Rp. 50.000,-/orang/hari atau Rp. 150.000,/orang/tahun; pengunjung lokal (dewasa) sebesar Rp. 2.500,-/orang/kunjungan, dan siswa sekolah/ anak sebesar Rp 1.000, -/orang/kunjungan. Hasil pungutan ini kemudian dibagi menjadi $80 \%$ digunakan untuk operasional dari DPTNB termasuk program konservasi yang dilakukan, dan $20 \%$ untuk pihak pemerintah dengan pembagian keseimbangan pusat dan daerah.

Perubahan terjadi pada sistem tarif sejak dikeluarkannya Peraturan Pemerintah No. 12 tahun 2014, sebagai berikut: pengunjung asing sebesar Rp. 200.000, -/orang/hari (Rp. 150.000,- untuk pusat dan Rp. 50.000,- untuk daerah) atau Rp. 300.000 ,-/ orang/tahun (Rp. 150.000 ,- untuk pusat dan Rp 150.000,- untuk daerah), dan pengunjung nusantara sebesar Rp. 7.500/orang/hari (Rp. 5.000,untuk pusat dan Rp 2.500,- untuk daerah).

\section{Hasil Pengelolaan}

Mengacu pada tujuan utama Taman Nasional Bunaken, yaitu: 1) konservasi keanekaragaman hayati, 2) mendukung penghidupan masyarakat lokal, dan 3) mengembangkan industri wisata alam, maka pada akhirnya, keefektifan pengolahan Taman Nasional Bunaken akan dinilai berdasarkan apakah tujuan pengolahan tercapai atau tidak. Pencapaian tujuan tersebut memerlukan strategi pengolahan jangka panjang dan pengukuran kemajuan terhadap tujuan tersebut, monitoring kondisi lingkungan, sosial dan ekonomi yang konsisten dan jangka panjang.

Penurunan ancaman telah menjadi fokus utama dari kegiatan pengelolahan sepanjang beberapa tahun terakhir melalui program untuk mengatur, meningkatkan kepatuhan, dan meningkatkan kesadaran. Telah ada kemajuan yang dibuat dalam mengurangi semaraknya beberapa ancaman penting terhadap nilai-nilai TNB, tetapi masih banyak kegiatan dan sikap manusia, yang secara langsung dan tidak, mengancam konservasi dan pengolahan berkelanjutan TNB dan daerah sekitar.

a. Kemajuan ke arah konservasi keragaman hayati

\section{- Menurunnya Pelanggaran sistem zonasi}

Penunjukan Taman Nasional Bunaken pada tahun 1991, dan adanya sistem zonasi pada tahun 1997, maka sejak saat itu Balai Taman Nasional Bunaken melakukan upaya menanggulangi praktikpraktik penangkapan ikan ilegal di seluruh kawasan Taman Nasional Bunaken, seperti penggunaan racun, kompresor dan pukat. Namun, sejak disetujuinya Sistem Zonasi Taman Nasional Bunaken hingga revisi zonasi pada tahun 2008, Balai Taman Nasional Bunaken memiliki instrumen

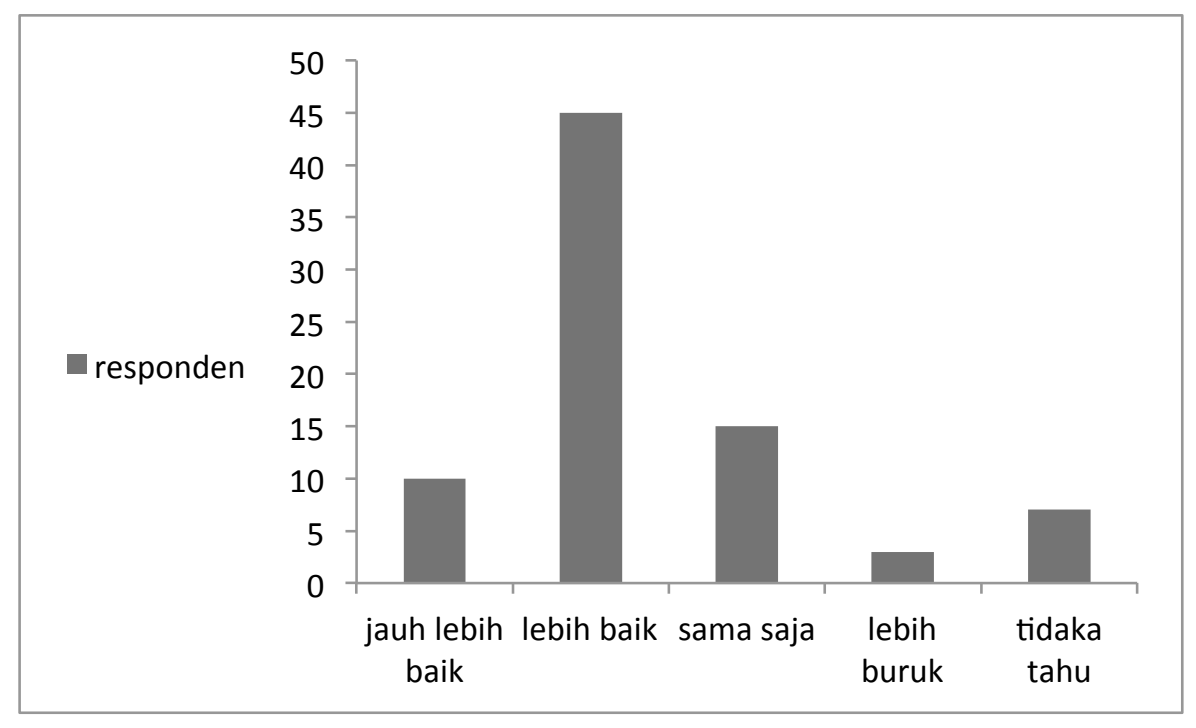

Gambar 3. Pandangan responden tentang sistem patroli sekarang dibandingkan tiga tahun lalu 
untuk menanggulangi penangkapan ikan berlebihan di Taman Nasional Bunaken. Hal yang sangat penting dalam hal ini adalah kawasan larangtangkap, yang terdiri dari zona inti, zona rehabilitasi, dan zona pemanfaatan pariwisata.

Hasil wawancara dengan responden tentang ada tidaknya perubahan situasi pelanggaran zonasi yang mereka lihat atau dengar dalam 3 tahun terakhir ditampilkan pada Gambar 4. Banyak responden menjawab 'tidak tahu'. Dari yang menjawab pertanyaan ini, hampir $50 \%$ mengatakan telah banyak penurunan pelanggaran dibandingkan 3 tahun lalu. Hal ini mengarah pada meningkatkan optimisme para pihak terhadap perbaikan aktual dari pengelola Taman Nasional Bunaken.

\section{- Pemboman Ikan}

Hasil laporan patroli dari Balai Taman Nasional Bunaken memperlihatkan tidak ada lagi kasus pemboman yang terjadi selama 3 tahun terakhir. Lebih dari $92 \%$ responden menyatakan, bahwa tidak pernah mendengar kejadian pemboman ikan selama 3 tahun terakhir. Sebagian lain menyatakan, bahwa terjadi sesekali (4\%) dan jarang terjadi $(2,5 \%)$. Hasil ini menunjukkan, bahwa sudah tidak ada lagi praktek pengeboman yang terjadi.

\section{b. Sosial Ekonomi}

Industri wisata merupakan sektor yang menyerap tenaga kerja terbesar dari penduduk setempat. Industri penyelaman sendiri di Sulawesi Utara mempekerjakan hampir 600 penduduk. Angka ini belum termasuk tenaga kerja pada homestay atau restoran. Banyak pengusaha wisata selam dan pemilik cottage menerapkan bantuan skala kecil kepada para pekerjanya, keluarga pekerja, desa, dan sekolah desa. Beberapa pengusaha tersebut juga membantu usaha kerja sama, seperti mendukung kegiatan patroli bersama. Kegiatan patroli bersama yang didukung oleh sektor swasta tidak hanya telah menyerap tenaga kerja dan membantu pengawasan kawasan tetapi juga membantu memberdayakan masyarakat setempat untuk berpartipasi dalam melindungi sumber daya laut.

Hasil pengolahan data penduduk bagian Selatan di mana sebanyak $82,5 \%$ menyatakan, bahwa kesejahteraan mereka 'membaik' ('meningkat'), hanya $5 \%$ penduduk yang mengatakan kesejahteraan hidup mereka 'memburuk'. Penduduk di bagian Utara TNB (30\%) menyatakan, bahwa kesejahteraan mereka 'tidak berubah', sama saja dalam tiga tahun terakhir, dan 7,5\% mengatakan kesejahteraan hidup mereka 'memburuk'. Hasil ini menunjukkan, bahwa kesejahteraan mayoritas penduduk Taman Nasional Bunaken stabil atau membaik dalam tiga tahun terakhir.

\section{KESIMPULAN}

Efektivitas pengelolaan Taman Nasional Bunaken menunjukkan kemajuan ke arah konservasi yang lebih baik di mana sangat sedikit pelanggaran di daerah zonasi sehingga berdampak pada menurunnya tingkat ancaman. Sosial ekonomi masyarakat Taman Nasional Bunaken meningkat lewat penyerapan tenaga kerja dan keuntungan lain dari usaha wisata, kesehatan, dan kesejahteraan

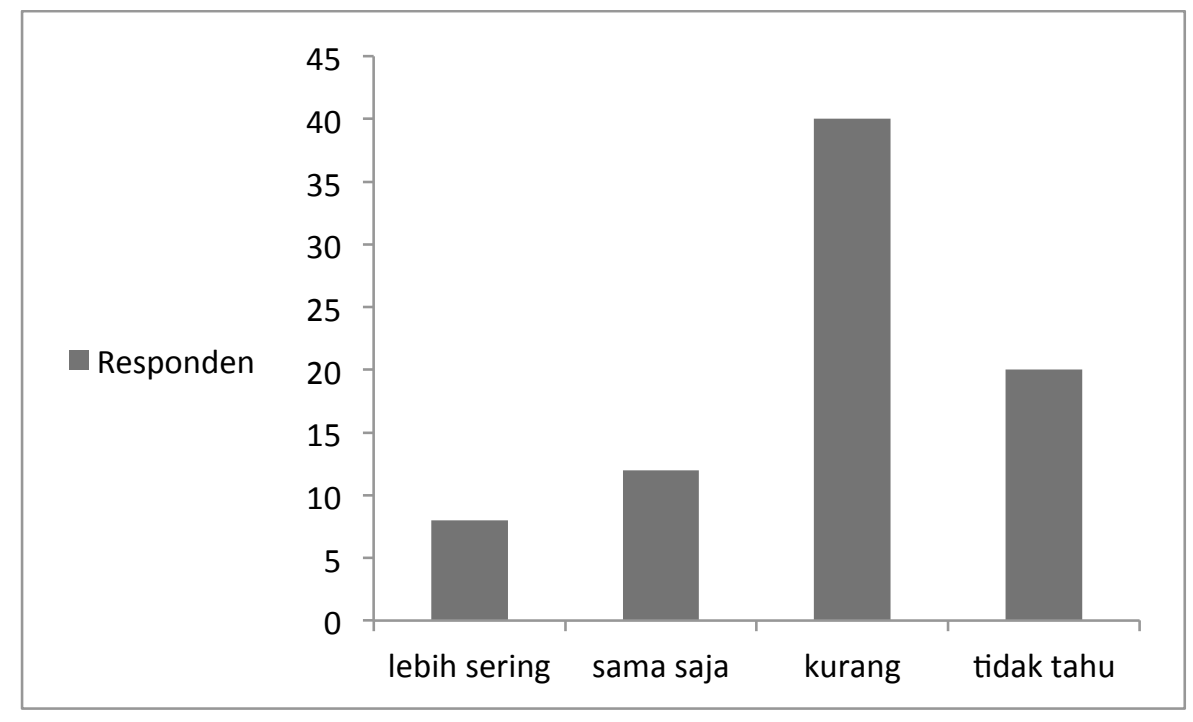

Gambar 4. Pandangan responden tentang seberapa banyak pelanggaran zonasi telah berubah selama tiga tahun terakhir 
mayoritas penduduk Taman Nasional Bunaken stabil atau membaik dalam tiga tahun terakhir.

\section{REFERENSI}

BALAI TNB (2009) Monitoring daerah pemijahan ikan karang di pulau Mantehage TNB, Manado. 62 hal.

COSTAL RESOURCES CENTER UNIVERSITY OF RHODE ISLAND (2003) Fostering marine conservation in Indonesia: Developing capacity to implement community-based marine sanctuaries. Final report (October 1999-April 2003) submitted to the david and Lucile pacard foundation, 26-38 hal.

DAHL-TACCONI N, GENEVA M, PAAT R, TASIDJAWA S. 2004. Evaluasi Keefektifan Pengelolaan Taman Nasional Bunaken. Rekomendasi untuk meningkatkan pengelolaan. $108 \mathrm{Hal}$.

DAHURI, R. 2008. Paradigma Baru Pembangunan Indonesia Berbasis Kelautan. Orasi Ilmiah: Guru Besar Tetap Bidang Pengelolaan Sumber DayaPesisir dan Lautan Fakultas Perikanan dan Ilmu Kelautan Institut Pertanian Bogor.

DEPARTEMEN KEHUTANAN REPUBLIK INDONESIA. Surat Keputusan Menteri Kehutanan No.328/Kpts.-II/86 Tahun 1986. Tentang Penetapan Kawasan Pulau Bunaken menjadi Cagar Alam Laut Bunaken-Manado Tua dan Kawasan Arakan hingga Wawontulap sebagai Cagar Alam Laut Arakan-Wawontulap

DEPARTEMEN KEHUTANAN REPUBLIK INDONESIA. Surat Keputusan Menteri Kehutanan No.444/Menhut-II/89 Tahun 1989. Tentang Penetapan Penggabungan Cagar Alam Bunaken dan Cagar Alam Arakan-Wawontulap menjadi Calon Taman Nasional.

DEPARTEMEN KEHUTANAN REPUBLIK INDONESIA. Surat Keputusan Menteri Kehutanan No.730/Kpts.-II/1991 Tahun 1991. Tentang Pembentukan Taman Nasional Bunaken.

DIREKTORAT JENDERAL KELAUTAN, PESISIR DAN PULAU-PULAU KECIL. 2006. Daerah perlindungan laut berbasis masyarakat. Buku Panduan. Volume 2. PT. Bina marina nusantara. Jakarta. Hal 1-15.

DIREKTORAT JENDERAL KELAUTAN, PESISIR DAN PULAU-PULAU KECIL.
2009. Undang Undang nomor 27 tahun 2007 tentang pengelolaan wilayah pesisir dan pulau-pulau kecil. Direktorat Jenderal Kelautan, Pesisir dan Pulau-pulau Kecil. Jakarta. 43 hal

EFFENDIE, M.I. 1997. Biologi Perikanan. Yayasan Pustaka Nusatama. Jakarta. 155 hal.

IUCN-CMP 2006. IUCN - CMP Unified Classification of Direct Threats, v. 1 (June 2006).

MANGUBHAI S. 2003. Memilai Keefektifan Pengelolaan Kawasan Lindung Laut. Buku Kerja Untuk Western Indian Ocean. $82 \mathrm{Hal}$.

MERRILL R AND J. DAVIE. 1996. The sustainable management of Bunaken National Park's mangroves. NRMP/USAID.

POMEROY,R.S., JOHN, E.P DAN LANI M.W. 2004. How is your MPA doing? A Guidebook of Natural and Social Indicators for Evaluating Marine Protected Areas Management Effectiveness IUCN-The World Conservation Union. Thaned Press Ltd, Margate, UK.

RARE 2009. Strategic Plan - RARE - Coral Triangle. 2010-2011 Marine Thematic Cohort. Indonesia - Malaysia - East Timor. Rare, Bogor, Indonesia.

ROBERTS, C.M. AND J.P. HAWKINS. 2000. Fully-protected marine reserves. a guide. WWF endangered seas campaign, 1250 $24^{\text {th }}$ street, NW, Washington, DC 20037, USA and environment department, University of York, York, Y010 5DD, UK.

SULISTIYO, B. 2004. Menata Wilayah Laut. Bab 2 dari Buku Menata Ruang Laut Terpadu. Penerbit PT Pradnya Paramitha, Jakarta.

TURAK, E AND DE VANTIER, L.M. 2003. Corals and coral communities of Bunaken National Park and nearby reefs, North Sulawesi, Indonesia: Rapid ecological assessment of biodiversity and status. Final Report to the International Ocean Institute Regional centre for Australia and western Pacific.

WEBER, J AND L. SAUNDERS. 1996. Managing a coral reef ecosystem in Indonesia. NRMP/ USAID.

YULIANTO I., at al. 2009. Laporan monitoring aspek sosial ekonomi dalam pengelolaan Taman Nasional Karimun Jawa. Bogor. 32 Hal.

Diterima: 10 November 2015

Disetujui: 16 Desember 2015 